\title{
2 Music hall and the railway
}

Music Hall WAS a booming industry in the UK during the late nineteenth century. By 1870, London had 33 music halls with an average audience capacity of 1500. Numbers of halls were growing in the provinces, Sheffield had ten and Manchester and Leeds both had eight, ${ }^{1}$ and by this time most English towns had access to at least one. Musical life in general had received a boost from the huge growth in cheap rail travel: brass bands and choirs could travel the country to take part in competitions and concerts; and music hall artists could move easily from venue to venue, town to town, performing the same repertoire. ${ }^{2}$ At the same time the music publishing industry was flourishing, largely because of the popularity of music hall. Towards the end of the nineteenth century most middle class homes owned an upright piano or a harmonium which became the focus of home entertainment: there was a huge market for sheet music with hit songs selling in their hundreds of thousands. ${ }^{3}$

Although the roots of music halls can be traced back in part to the rough drinking saloon concerts in the first half of the nineteenth century, the first true halls emerged in the 1850s and became increasingly up market. The first boom was in the 1860s and early 1870s with the halls becoming bigger, more expensive and luxurious in their décor and architectural design, until they eventually transformed into the more respectable variety theatres at the turn of the century. Going to the music hall was a social event: people went along in groups to enjoy the entertainment sitting at tables being served by waiters, eating dishes such as pease pudding, oysters and steak and kidney pie $\mathrm{p}^{4}$, drinking and smoking. The audience was part of the performance, heckling the performers and joining in with the choruses. Contrary to what is commonly supposed, the halls were not the exclusive preserve of the working classes. 
Although a good proportion of the singers were working class, most of the composers were middle class and, in general, the demographic of the audience cut across classes with a mainstay of upper working class and lower middle class. Most were young men under 25, some were much younger than that, especially in the cheaper gallery seats.

Recent technological innovations in printing meant that music had become much easier to print. The system for printing scores had changed from using engraved metal plates to moveable type which was much more economic, as was the move to colour lithography for the pictorial covers. The frontispieces were often highly elaborate illustrations of contemporary scenes and music hall artists and are of great historic interest today. Music hall songs only required a couple of sheets of paper to produce and they sold well, consequently publishers of the time relied on this market. ${ }^{5}$ However, the sheet music for music hall songs cost three or four shillings so most copies were found in middle class homes. All this meant that new songs could spread around the country quickly and become part of the national culture. Thousands of catchy new songs appeared dealing, often humorously, with matters of everyday life: love, marriage, current fashions, social comment and contemporary events. Songs were often written for specific artists, and them alone, to perform.

In an age when the railways had transformed so many people's lives, it is not surprising that there was a large repertoire of songs about railway journeys, station porters, guards, trains and the escapades of the passengers. As Rudyard Kipling wrote to his friend James Benion Booth "Those old music-hall ditties. . supply a gap in the national history, and people haven't yet realised how much they had to do with national life.' In Music and Politics, John Street argues that music has the 'capacity to capture historical experience' and that it 'embodies or conveys politics.' The lyrics of songs in the music hall looked at life from a working-class perspective - a social commentary on the way that ordinary people lived.

Many of the music hall songs told stories, some were sentimental, many were humorous often with an element of self-mockery, and countless rested on sexual innuendo and double entendre. In terms of the subject matter of songs connected with the railway, several common themes can be found: songs featuring railway employees; tales of railway excursions; and songs narrating the possibility of being tricked by a pretty girl when alone in a carriage, a preoccupation of contemporary Victorian society with cases of such being much reported in newspapers. The film critic John Huntley described music 
hall as the 'original permissive society' which recognised the 'utter stupidity of the artificially refined exterior with which Victorian society attempted to cover up its less savoury truths. ${ }^{8}$

\section{0 music hall songs about the railways}

\begin{tabular}{|c|c|c|c|}
\hline SONG TITLE & $\begin{array}{l}\text { MUSIC HALL } \\
\text { ARTIST }\end{array}$ & SONGWRITER(S) & DATE \\
\hline \multicolumn{4}{|l|}{ Jobs on the railway } \\
\hline The lost luggage man & George Robey & & \\
\hline Give me a ticket to heaven & $\begin{array}{l}\text { Denham } \\
\text { Harrison }\end{array}$ & $\begin{array}{l}\text { Richard Elton } \& \\
\text { Denham Harrison }\end{array}$ & \\
\hline All change for Llanfairfechan & Wilkie Bard & $\begin{array}{l}\text { Worton David \& } \\
\text { George Arthurs }\end{array}$ & \\
\hline I kept on waving my flag & $\begin{array}{l}\text { George Formby } \\
\text { Senior }\end{array}$ & & \\
\hline The Muddle Puddle porter & Lionel Brough & $\begin{array}{l}\text { George Grossman } \\
\text { Junior }\end{array}$ & \\
\hline Railway porter, Dan & Henri Clark & $\begin{array}{l}\text { Harry Hunter \& G. } \\
\text { D. Fox }\end{array}$ & 1884 \\
\hline Oh! Mister Porter & Marie Lloyd & & 1892 \\
\hline The wheeltapper's song & & $\begin{array}{l}\text { Clifford Seyler \& } \\
\text { Wolseley Charles }\end{array}$ & 1923 \\
\hline Johnny the engine driver & Annie Adams & G. W. Hunt & 1867 \\
\hline The railway fireman & Harry Gordon & & \\
\hline The railway guard & Arthur Lloyd & Alfred Plumpton & 1866 \\
\hline The railway guard & Will Fyffe & Will Fyffe & \\
\hline The railway guard & Dan Leno & George LeBrunn & 1890 \\
\hline $\begin{array}{l}\text { The railway belle and the railway } \\
\text { guard }\end{array}$ & Harry Clifton & Harry Clifton & 1865 \\
\hline \multicolumn{4}{|l|}{ Excursion trains } \\
\hline The cheap excursion train & Lillie Langtry & J. P. Harrington & 1898 \\
\hline Rosie had a very rosy time & Marie Lloyd & Fred Murray & 1909 \\
\hline I couldn't get in! & Charles Bignell & J. P. Harrington & \\
\hline It ain't all honey and it ain't all jam & Vesta Victoria & $\begin{array}{l}\text { Fred Murray \& Geo. } \\
\text { Everard }\end{array}$ & 1906 \\
\hline The young man on the railway & Harry Clifton & W. H. Brinkworth & 1865 \\
\hline
\end{tabular}




\begin{tabular}{|c|c|c|c|}
\hline A little idea of my own & George Robey & & \\
\hline \multicolumn{4}{|l|}{ Train journeys } \\
\hline \multicolumn{4}{|l|}{$\begin{array}{l}\text { Show me a train that goes to } \\
\text { London }\end{array}$} \\
\hline Don't stick it out like that & Fred Earle & $\begin{array}{l}\text { Fred Murray \& Fred } \\
\text { W. Leigh }\end{array}$ & 1901 \\
\hline I looked out of the window & Fred Earle & & \\
\hline Tickle me Timothy do & Billy Williams & $\begin{array}{l}\text { R. P. Weston \& F. J. } \\
\text { Barnes }\end{array}$ & 1908 \\
\hline $\begin{array}{l}\text { He's gone where they don't play } \\
\text { billiards }\end{array}$ & Sam Mayo & $\begin{array}{l}\text { J. P. Harrington \& } \\
\text { Sam Mayo }\end{array}$ & \\
\hline Let's go round and have a taster & Ernie Mayne & & \\
\hline The railway station sandwich & Will Evans & $\begin{array}{l}\text { W. H. Wallis \& F. E. } \\
\text { Terry }\end{array}$ & 1902 \\
\hline Dear old Shepherd's Bush & Nat D. Ayer & $\begin{array}{l}\text { Nat D. Ayer \& } \\
\text { Clifford F. Grey }\end{array}$ & 1916 \\
\hline \multicolumn{4}{|l|}{ And the leaves began to fall } \\
\hline London, Chatham and Dover & "Jolly" John Mash & G. W. Hunt & 1865 \\
\hline Take me back to dear old Blighty & $\begin{array}{l}\text { Lily Morris, Ellie } \\
\text { Retford }\end{array}$ & & \\
\hline The train that's taking you home & Will Fyffe & Will Fyffe & 1929 \\
\hline I want you to notice my leggings & Wilkie Bard & F. Leo & \\
\hline The underground railway & $\begin{array}{l}\text { Marcus } \\
\text { Wilkinson } \\
\end{array}$ & Watkin Williams & 1863 \\
\hline The Tuppenny Tube & R. G. Knowles & $\begin{array}{l}\text { Edgar Bateman \& } \\
\text { Henry E Pether }\end{array}$ & 1900 \\
\hline The husband's boat & Alfred Vance & $\begin{array}{l}\text { Frank W. Green \& } \\
\text { Alfred Lee }\end{array}$ & 1869 \\
\hline Bang went the chance of a lifetime & George Robey & $\begin{array}{l}\text { George Robey \& Sax } \\
\text { Rohmer }\end{array}$ & 1908 \\
\hline You can't punch my ticket again & Cissie Kent & Charles Collins & 1897 \\
\hline Watching the trains come in & Jack Pleasants & Frank Leo & 1916 \\
\hline Watching the trains go out & Jack Pleasants & William Hargreaves & 1912 \\
\hline Oh blow the scenery on the railway & George Lashwood & F.W. Leigh \& G. Arthur & 1910 \\
\hline $\begin{array}{l}\text { There's danger on the line. The } \\
\text { great semaphore song }\end{array}$ & $\begin{array}{l}\text { G. H. } \\
\text { MacDermott } \\
\end{array}$ & G. P. Norman & 1875 \\
\hline \multicolumn{4}{|c|}{ Travelling in a confined carriage } \\
\hline The kiss in the railway & & G. H. Mackey & 1864 \\
\hline $\begin{array}{l}\text { Where do flies go in the winter } \\
\text { time? }\end{array}$ & $\begin{array}{l}\text { Jack Pleasants, } \\
\text { Sam Mayo }\end{array}$ & $\begin{array}{l}\text { Sam Mayo \& Frank } \\
\text { Leo }\end{array}$ & \\
\hline
\end{tabular}




\begin{tabular}{|l|l|l|l|}
\hline Tommy make room for your uncle & $\begin{array}{l}\text { Marie Lloyd, W. B. } \\
\text { Fair, Tony Pastor }\end{array}$ & T. S. Lonsdale & 1876 \\
\hline Oh! Mister what's-er-name & Marie Lloyd & $\begin{array}{l}\text { Fred Murray \& } \\
\text { Kenneth Lyle }\end{array}$ & 1907 \\
\hline Sexual symbolism of trains & Clarkson Rose & & 1912 \\
\hline He missed his train again & Marie Lloyd & $\begin{array}{l}\text { G. Rollit \& George Le } \\
\text { Brunn }\end{array}$ & 1897 \\
\hline I've never lost my last train, yet & $\begin{array}{l}\text { "Viscount" Walter } \\
\text { Munroe }\end{array}$ & & $\begin{array}{l}\text { C. G. Cotes \& Bennett } \\
\text { Lcott }\end{array}$ \\
\hline $\begin{array}{l}\text { What did she know about } \\
\text { railways }\end{array}$ & Marie Lloyd &
\end{tabular}

Most songs are in verse and chorus form with lilting melodies and catchy choruses. In musical terms, they were pretty straightforward because they had to be. The audience customarily joined in with the chorus, consequently many songs have a narrow melodic range making them easier to sing. The harmony is usually very basic with the use of a few simple chords, many using what is now referred to as the three chord trick. The most successful songs were the result of the combination of a good tune, witty memorable lyrics, and a good performer who often acted the part of the character they were singing about. 'Oh! Mister Porter', as sung by Marie Lloyd, one of the biggest music hall stars, combined all these factors and was hugely successful.

\section{Marie Lloyd and Oh! Mister Porter}

Marie Lloyd (1870 - 1922) was born in the working-class area of Hoxton in East London. She had a long career with a large number of hits, topping the bill at music halls in both the United Kingdom and the United States and acting in pantomime with two other music hall stars - Dan Leno and Tich. Her songs were frequently character songs, often quite risqué, and full of double meanings, one of the most famous being 'What did she know about railways' with the infamous lines Someone wanted to punch her ticket/ The guards and porters came round by the score/ And she told them all she'd never had her ticket punched before. This was during the period of middle-class moralism with its Victorian ideal of womanhood, one of wife and mother and the guardian of Christian virtues- a cult of domesticity which rested firmly on the double 
standard of sexual conduct. ${ }^{9}$ Peter Honri in Working the Halls writes that Marie Lloyd was 'one of the first people to recognise that there was a great deal to be said for 'doing and speaking in public what Victorian society did in private. ${ }^{10}$ In some songs the trains themselves were symbolic of sexual activity. For example, in her song, 'I've never lost my last train, yet' the chorus uses the 'last train' to symbolise a 'modest little maiden's virginity.

Yes, I've learnt to know the bliss

Of a stolen little kiss

When you heave a sigh and softly murmur "Pet"

As you gaze into his face

Wrapt in amorous embrace

But I've never lost my last train yet, $\mathrm{Oh}$ no

I have never lost my last train yet. ${ }^{11}$

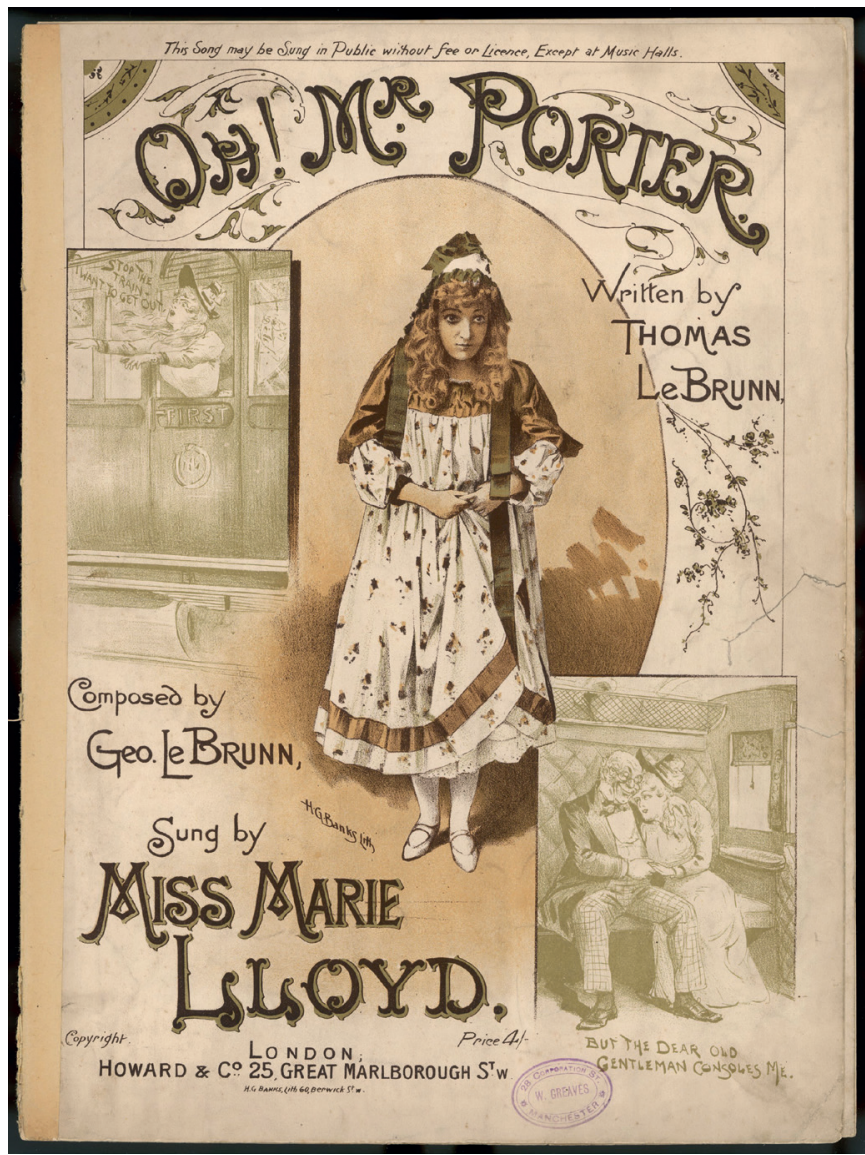

Oh! Mr Porter, Miss

Marie Lloyd

Chronicle / Alamy

Stock Photo 
'Oh! Mister Porter' was written in 1892 by George Le Brunn (1864 - 1905) and his brother Thomas and was taken on tour that year by Marie Lloyd. It was a huge success. The song skips along in $6 / 8$, moving mainly by step to make it easy for the audience to join in the chorus. As the writer Max Beerbohm commented after a performance "The flurry, the frantic distress of it ...Marie was bursting with rapture and made us partakers of it. ${ }^{12}$ On the face of it, 'Oh! Mr Porter' is about a young woman, an innocent abroad, returning from a visit to her old aunt in London and getting on the wrong train which goes beyond her stop. However, the story goes on to reveal that she meets an old gentleman who grasped her leg, pulled her back and she sank into his arms where she laid her trembling head. To quote the writer Arnold Bennett of a performance by Lloyd at the Tivoli Theatre: 'All her songs were variations on the same theme of sexual naughtiness. No censor would ever pass them, and especially he wouldn't pass her winks and silences. ${ }^{13}$ So when we bear in mind Lloyd's infamous nods and winks and telling looks, another reading might tell us that she 'has gone too far'. The last verse includes the lines If you make a fuss of me and on me do not frown / You shall have my mansion, dear, away in London town. The fantasy of being saved from poverty by a rich benefactor, often an older man, is another common theme in music hall songs.

Lloyd made a huge amount of money in her lifetime but she never forgot her modest roots. In an 1895 interview in the Daily Sketch it was reported that she was paying nightly for one hundred and fifty beds for the homeless and destitute of "Darker London". 14 When the music hall workers went on strike in 1907, she gave generously to the strike fund and was there on the picket lines. At the age of 52 she collapsed on stage at the Edmonton Empire and died three days later. The writer Max Beerbohm described her funeral as the best-attended in London since that of the Duke of Wellington. The poet T S Eliot reflected on her death in the American literary magazine The Dial:

whereas other comedians amuse their audiences as much and sometimes more than Marie Lloyd, no other comedian succeeded so well in giving expression to the life of that audience, in raising it to a kind of art. ${ }^{15}$ 


\section{Oh! Mister Porter}

Lately I just spent a week with my old Aunt Brown

Came up to see the wond'rous sights of famous London Town

Just a week I had of it, all round the place we'd roam

Wasn't I sorry on the day I had to go back

home.

Worried about with packing, I arrived late at the station

Dropped my hat box in the mud, the things all fell about

Got my ticket, said good-bye "Right away" the guard did cry

But I found the train was wrong and shouted out,

Chorus: Oh! Mr Porter what shall I do I want to go to Birmingham And they're taking me on to Crewe Send me back to London as quickly as you can Oh! Mr Porter what a silly girl I am. The porter would not stop the train.
But I laughed and said, "You must

Keep your hair on Mary Ann, and mind that you don't bust".

Some old gentleman inside declared that it was hard

Said, "Look out of the window, Miss and try and call the guard."

Didn't I, too, with all my might I nearly

balanced over

But my old friend grasp'd my leg, and pulled me back again

Nearly fainting with the fright, I sank into his arms a sight

Went into hysterics but I cried in vain,

\section{Chorus}

On his clean old shirtfront then I laid my trembling head

"Do take it easy, rest awhile," the dear old chappie said

"If you make a fuss of me and on me do not frown

You shall have my mansion, dear, away in London Town."

Wouldn't you think me silly if I said I could not like him?

Really he seemed a nice old boy, so I replied this way

"I will be your own for life, your immy doodle um little wife

If you'll never tease me any more I say.

\section{Chorus}

\section{The cheap excursion train}

With the arrival of the railways came the first excursion trains - almost from the very start. Within a few weeks of its opening in 1830, the London and Midland Railway (LMR) took an excursion of 150 Manchester Sunday school children to Liverpool. Cheap excursion trains were hugely popular in Britain throughout the nineteenth century and into the twentieth century, much 
more so than anywhere else on the continent. It is easy to see why such train trips were instantly successful. Prior to this, journeys by road were on foot, horseback or in a carriage (something that was too expensive for most people). Excursions for pleasure usually took place on water, on canals or rivers, and sometimes in steamboats, but even steamboats did not have the capacity to carry large numbers.

Excursion trips by train, on the other hand, had reduced fares making them available to many people and having the capacity to transport huge numbers of them. The Great Exhibition of 1851 attracted thousands of visitors carried there by trains, no exact numbers are known because returns were not given, but they probably ran into the hundreds of thousands. Most trips were to the seaside, pleasure grounds, and sports event including prize fights (even though they were illegal). They were organised by newly created travel agents, business works, friendly societies, and the temperance societies which flourished at the time. Many trips were for pure pleasure but others, often run by the mechanics' institutes, were instructional. There was a seemingly endless stream of passengers keen to take the opportunity to travel outside their immediate locale and, in order to cater for them, railway companies added more and more carriages. In August 1844 an excursion was organised from Wakefield to Hull, with 97 carriages. This was a record for the time.

\section{A MONSTER TRAIN}

A special pleasure train of the Manchester and Leeds Railway left Wakefield for Hull on Monday last, consisting of 97 carriages, with the extraordinary, and we believe, unprecedented number of 4000 passengers, composed of the "Ancient Order of Foresters", other lodges, and their friends. ${ }^{16}$

The music hall song 'The cheap excursion train' was written and composed by J. P. Harrington $(1865-1939)$ in $1898 .{ }^{17}$ It was written for Lillie Langtry (1877 - 1965) a music hall comedian known as the Electric Spark (not to be confused with her contemporary the well-known actress Lillie Langtry, the 'Jersey Lily'). By the time this song was written, monster trains were no longer around, instead several trains were put on at once when needed. Contemporary accounts of nineteenth century railway excursions depict them as jolly affairs, high-spirited, often chaotic and certainly memorable. Music and singing often played a part. Street's claim that music has the 'capacity to 
capture historical experience' is reinforced by the first verse and the chorus of 'The Cheap Excursion Train' where all these characteristics of excursions are captured in the lyrics.

The reference to 'Ladies smoking' is interesting. Smoking was generally prohibited on trains from the 1830s to 1868 when the Railway Regulation Act made it compulsory for railway companies to provide designated carriages for smokers, before this the approach had been inconsistent and people smoked 'in defiance of the bye-laws and the penalties' as evidenced by this passage from The Railway Traveller's Handy Book of 1862:

\section{SMOKING}

We believe that on certain occasions the stringency of the prohibition is relaxed, and we were once present at the arrival of a train from Doncaster, during race time, which train had more the odour of a divan18 than anything else, and every other passenger who alighted therefrom, held between his lips a partially consumed cigar. ${ }^{19}$

Although women were permitted to use smoking compartments, the carriages were seen as a male domain and women who encroached upon this territory were perceived as 'invaders'. Smoking was seen as the preserve of prostitutes and lower-class women: on the whole middle-class women did not smoke, those who did so were regarded as 'fast'.

The second verse gives us another snapshot of late nineteenth-century society in its depiction of the upper-class toff 'Bertie, with his eye glass' and his fancy way of speaking. The excursion trip was an important part of working-class culture, but the social composition of the passengers on the trains cut across classes. The 'swell', as such types with their resplendent dress and arrogant manner were commonly known, was a stereotype much parodied in the music hall to the extent that there was a particular type of music hall performer who specialised in their portrayal known as the lion comique. The well-known song 'Champagne Charlie' was amongst their repertoire.

Verse three encapsulates a common attitude held in the late nineteenth century in its description of the way that men took advantage of the darkness of the confined space of the carriage when travelling through a tunnel and used this as an opportunity to grope women (or worse). This concern was fuelled by regular and sensationalist reports of attacks and sexual assaults on female 
passengers in the press. The Railway Traveller's Handy Book of 1862 provides the following cautionary advice:

\section{CAUTION IN PASSING THROUGH TUNNELS}

Male passengers have sometimes been assaulted and robbed, and females insulted, in passing through tunnels...In going through a tunnel, therefore, it is always as well to have the hands and arms ready disposed for defence, so that in the event of an attack, the assailant may be instantly beaten back or restrained. ${ }^{20}$

\section{The cheap excursion train}

Puff, puff, puff, puff goes the engine, now we're starting off again

For a day out in the country by a cheap excursion train

Chaps and girls sit in the corners, all's as cosy as can be

Some have seats and others haven't, some are glad to take a knee

Doors a-banging - banjos twanging to the latest song

Ladies smoking - fellows joking - Now we shan't be long.'

Chorus: Now we're off again, on a cheap excursion train

Any amount of chaps and gals, all in their Sunday falderals

Singing a lively song, 'Life on the ocean main'

Going away for a lively day by the cheap excursion train.
Then there's Bertie, with his eye-glass Thinks the company really is beastly, bally, awfully vulgar

With its songs and sandwiches, just imagine

Bertie's horror

When a lady shouts out quick " Ere I say - you with the winder

Hold my baby, 'arf a tick.'

Some reciting - others fighting, swearing all the way

Babies squalling - porters bawling- there's a peaceful day.

\section{Chorus}

Now we've got into a tunnel, all's as lively as can be

'Keep your hands out of my pockets.' 'Who's that tickling my knee?'

'You leave off, you, Bill! I know you- I can tell you by your squeeze'

'Leave off-do! Oh mother, mother. Porter turn the lights up please.'

Lights are gleaming - girls cease screamingthey once more look gay

Gay, but rumpled - hats all crumpled - what a tunnel, eh?

\section{Chorus}

It would be wrong to give the impression that all music hall songs are full of sexual innuendo. Another characteristic of music hall lyrics was their play upon words. 'Railway porter, Dan' is a good example of this with its humour resting on the witty use of puns on place names, for example: If you're fond of 
billiards go to Kew and then to Poole / And to the Scilly Islands if you fancy you're a fool and The Milkmen should go more to Cowes, I very often say / And Jockeys should be off to Ryde, or else Horse-trail-i-a. The song was written and composed by Harry Hunter and G D Fox for the performer Henri Clark.

\section{Railway porter, Dan}

I am a Railway Porter and my mates all call me Dan

I earn as many hápence as a Railway Porter can My wages are a pound a week, which isn't very fat

When there's a wife and family to see to out of that

It takes me all my time I know, to find them bread and cheese

And I should have no dinners but for my gratuitous

Gratuities are sixpences and threepences and bobs

Which I get hold of now and then for waiting on the nobs

Chorus: Take your seats for Leicester, Chester, Birmingham and Crewe

See your luggage labelled, for the place you're going to And if you are a Captain or a Colonel or a man You can find a little sixpence for the Porter Dan

Now if you'd like a journey that will suit you, don't you know

Just tell me what you are and then I'll tell you where to go

If you're fond of billiards go to Kew and then to Poole

And to the Scilly Islands if you fancy you're a fool If you're a waiter you should go of course to Table Bay

And if you are a donkey, then you ought to go to Bray

Go to the Sandwich Islands if you're hungry and would dine

But if you're fond of bloaters go to Herrin'-onthe-Rhine

\section{Chorus}

There's the Isle of Man for ladies who are looking out for mates

For lovers who've made up their minds, there's the United States

For those who want divorces, Sunderland of course is best

And all the babies certainly prefer to go to Brest

All those who like a game of whist should cut at once for Deal

And pugilists to Box Moor go when they have been to Peel

Bookbinders should be happy, if to Russia they are bound

And invalids be glad if they arrive at Plymouth Sound

\section{Chorus}

The Milkmen should go more to Cowes, I very often say

And Jockeys should be off to Ryde, or else

Horse-trail-i-a

The Mashers should to Starch Green go to keep their collars stiff

And Tenor singers make a note to go to Tenerife The girls should go to Kissingen, there is no doubt they do The boys should go to Darlington, to Ems and

Nancy too

The Queen should go to Queensland though it's far across the sea

And the Prince of Wales in Kingsland then would very welcome be.

\section{Chorus}


Porters were hired by railway companies from the beginning of the railways with LMR being the first to employ them in 1830. Their general duties were to give directions to board trains, to stow passengers' luggage and then to unload it and to carry it to the awaiting omnibuses. Porters in large stations operated in gangs with specific tasks whereas in small country stations porters also took on more general tasks from ticket selling and collecting, to cleaning waiting rooms. Many country porters also took on the role of signal man. Porters were often recruited from the country. ${ }^{21}$ Physical standards were high, employees needed to be healthy, have good eyesight and, for the majority of companies, should be able to read and write. ${ }^{22}$ For most of the nineteenth century, they were paid 17 shillings a week, which, although it was low, was an improvement on, for example, the wages of an agricultural labourer. Some railway companies prohibited porters from accepting gratuities, but in practice tips were usually accepted in order to supplement low pay. The Railway Traveller's Handy Book of 1862 gives the following advice:

\section{HIRING PORTER}

If a person does not require a vehicle, he will seldom have any difficulty in finding a porter to carry his luggage. A crowd of men and boys are usually to be met with outside the terminus who, for a trifling fee, will convey the luggage to any part of the town. It would be well to hire a clean and honest-looking messenger, and also to take the precaution of making him walk on in front, as you will then have your eye upon him, and he cannot well decamp without your knowledge. On the principle of seeking information from everybody, you may, while jogging onwards, glean from your luggage-bearer such items of intelligence as will prove advantageous. ${ }^{23}$

\section{The Music Hall Artistes Railway Association (MHARA)}

Music hall artistes were constantly on tour and, although the growth of rail travel meant that they were able to move from town to town, this was not without both expense and difficulties. There were often huge amounts of equipment to be transported: not only the artistes and their personal luggage, but also scenery, props, and costumes. Against a background of general disquiet with the railways, music hall artistes were constantly seeking improvements to both fares and timetabling. During the late nineteenth century they formed 
pressure groups, notably the MHARA, and negotiated with the railways to secure better travelling conditions for their number.

The Railway Regulation Act 1844 and the Cheap Trains Act of 1883 Acts had addressed some passenger issues, ensuring that 3 rd class passengers should be protected from the weather at a fare of $1 \mathrm{~d}$ per mile and that these fares should be exempt from taxes, but the acts only set out the minimum quality obligation of rail passenger service. Improvements beyond this were still left to the railway companies. ${ }^{24}$ At a time when railways provided the only reliable means of long-distance travel, a large part of the problem for theatre companies was that the weekly change over from one theatre to another, ready to work again on Mondays, had to take place on Saturday nights because of the slowness and infrequency of trains on Sundays. This was very inconvenient. In the early 1880s John Bosworth, an enterprising railway clerk employed by Midland Railway, came up with a better system to accommodate the needs of theatrical traffic. Bosworth organised special Sunday trains and subsequently became a manager of theatrical traffic for Midland Railway. Bosworth's system involved theatrical companies booking their journeys in advance which meant that he was able to schedule his Sunday Specials in such a way that one train could cater for several theatre companies at once. There are several letters and articles of fulsome praise for the Sunday Specials in The Era, then known as 'The Great Theatrical Journal'. On the 12 December, 1885, it included the following report:

The Midland Railway conveyed thirty theatrical and operatic companies over their line on Sunday and Monday last, numbering 613 members of the profession. As many as 252 members arranged to travel by one train on Sunday... from Liverpool to London. Fifty seven vehicles were provided for the convenience of the parties. Fifty two of these belonged to the Midland Company, and the arrangements were efficiently carried out by $\mathrm{Mr}$ John Bosworth, the theatrical travelling agent of that company. ${ }^{25}$

However many more pieces in The Era during the 1880s reflected a general disquiet with railway companies and their price discrimination, an object of suspicion and led many to perceive them as monopolists. ${ }^{26}$ This ability to discriminate caused problems for theatre companies in the constantly changing charges the railway companies made for luggage. The following extract from a short article is typical. It was written at a time when changes 
were made to the amount of excessive baggage that could be carried on the train without incurring charges.

...What confidence will be felt by capitalists in starting touring enterprises under a sort of Reign of (Railway) Terror, when none can say what the next despotic decree may be? Will not the railway companies find themselves the losers, by the constant diminution of theatrical travellers? A stingy policy is generally a losing one in the end. Let the Boards think over the matter, and perhaps they may rescind or modify their resolution... ${ }^{27}$

Later that year The Stage made the point that "The amount paid in fares by the profession to the railway companies must form a very valuable addition to their receipts, a little courtesy and attention should therefore be paid in return'. ${ }^{28}$

Partly as a result of this dissatisfaction with the railways, the Music Hall Artistes Railway Association (MHARA) was formed in 1897 and by 1900 had a list of 5,196 members. ${ }^{29}$ Its founding members included several leading artistes: Dan Leno; ${ }^{30}$ the ventriloquist F W Millis; and the comedian Charles Coborn. The MHARA was officially apolitical and focused on campaigning for railway travel concessions. ${ }^{31}$ In 1897 The Stage reported that 'a deputation from the MHARA' approached the Railway Clearing House (RCH) 'on a question of a reduction of railway rates. ${ }^{32}$ Consequently, it negotiated special train fares for the transport of touring companies and their baggage. Members received a $25 \%$ discount on train fares when travelling in parties of five or more, considerably reducing the expensive costs. Several more meetings with the $\mathrm{RCH}$ followed in the quest for further concessions. ${ }^{33}$ These meetings are well documented by contemporary theatre papers such as The Stage and The Era. ${ }^{34}$

Membership of the MHARA continued to rise and in 1905 The Stage reported the "committee wishes to heartily thank the several theatrical managers of the railway companies for their invaluable co-operation. ${ }^{35}$ In 1912 they met again with the $\mathrm{RCH}$ pursuing 'a peaceful path, securing for its privileged members a satisfactory reduction in travelling expenses. ${ }^{36}$ By way of example, a company of 30 travelling 50 miles with two trucks to carry all of their equipment would pay $75 \%$ of the standard fare rate for each member of the company. They would get one baggage truck free and would pay for the other at $3 \mathrm{~d} / \mathrm{mile}$.

This is not to say that all the travelling problems for music hall artistes were over. In 1906 the MHARA joined up with other workers' organisations to 
form a trade union - the Variety Artistes Federation and in 1907, boosted by the membership of the musicians and stage hands unions, they took part in a music hall strike against working conditions. These conditions included the banning of last minute changes in venues and timetables, a matter of much concern for the large number of artistes who often performed in several theatres in one week and needed to book in advance planning to get from venue to venue as cheaply and efficiently as possible.

In 1914, following a large number of fires in music halls, London County Council imposed stricter controls which included banning eating and drinking in the auditorium - part of the essence of music hall entertainment. World War I saw a surge in popularity as performers were rallied to promote the war with patriotic calls to arms and morale-boosting songs. However, the interwar years saw a decline of the halls and a more respectable type of music hall entertainment arrived under the name of 'variety'. Competition from cinema, upcoming jazz and swing bands, and the outlet of radio led to the gradual demise of music hall and, by the onset of World War II, music hall had virtually disappeared.

\section{Endnotes}

1 http://www.bl.uk/onlinegallery/onlineex/vicpopmus/t/015hzz00001772du00031006.html

2 Dave Russell. Popular music in England. 1840-1914: A social history (Manchester: Manchester University Press, 1987).

3 Ruth Towse . "Copyright Auctions and the Asset Value of a Copyright Work." Review of Economic Research on Copyright Issues 13 no. 2: 83-99.

4 http://www.bl.uk/onlinegallery/onlineex/vicpopmus/t/015hzz00001772du00031006.html

5 Towse, “Copyright Auctions", 85.

6 P J Keating. The Working Class in Victorian Fiction. (London: Routledge and Kegan, 1971): 160.

7 John Street. Music and politics. (Cambridge: Polity Press, 2012).

8 John Huntley cited in Peter Honri's Working the Halls. (London: Futura Publications, 1974): 89.

9 J Mitchell and A Oakley. The Rights and Wrongs of Women. (London: Pelican, 1976): 61.

10 Honri, Working the Halls, 91.

11 Chorus of 'I've never lost my last train yet', written and composed by G. Rollit \& George Le Brunn, 1912.

12 Richard Anthony Baker. British Music Hall: An Illustrated History.(Barnsley: Pen \& Sword Books Ltd, 2014): 138

13 Arnold Bennett. The Journals of Arnold Bennett 1896-1910. (London: Casell Ltd., 1932).

14 Daily Sketch, 25 December, 1895. 
15 'London Letter' in December 1922 edition of The Dial.

16 The Scotsman, 14 August, 1844

17 As advertised in The Era, 16 July, 1898.

18 The word 'divan' is used here to mean a coffee house or smoking room.

19 Jack Simmons, ed. Railway Traveller's Handy Book of 1862. (Bath: Adams \& Dart, 1971): 66-7.

20 Simmons, Railway Traveller's Handy Book, 74-5

21 Simmons, Railway Traveller's Handy Book, 98-9.

22 P W Kingsford. Victorian Railwaymen. The emergence and growth of railway labour 1830-1870. (London: Frank Cass, 1970): 9.

23 Simmons, Railway Traveller's Handy Book, 98-9.

24 Huroki Shin. "Have consumer movements enhanced transport justice? Passenger representation on Britain's railways before 1947." In Transport policy: learning lessons from history. Colin Divall, Julian Hine, Colin Pooley eds. (Burlington, VT: Ashgate Publishing Company, 2016): 81-3.

25 "Theatrical Gossip" in Era, 12 December, 1885.

26 P J Cain, "Railways and price discrimination: the case of Agriculture, 1880-1914". (Business History 18 no. 2, 1976): 190.

27 "The Profession and the Railways" in The Era, 12 April, 1884.

28 The Stage, 21 November, 1884.

29 The Era, Dec 1, 1900.

30 Famous for singing the music hall song 'The Railway Guard'.

31 Peter Bailey, ed. Music Hall: The Business of Pleasure. (Milton Keynes: Open University Press, 1986): 180 .

32 The Stage, 17 June, 1897.

33 Railway Clearing House Committee Minutes and Reports. https://discovery.nationalarchives. gov.uk/details/r/C1793093

34 Other reports of the activities of the MHARA can be found in the Music Hall and Theatre Review, The Referee and the London and Provincial Entr'acte.

35 The Stage, 19 October, 1905.

36 L Carson, ed. The 1913 Stage Yearbook (London: Carson \& Comerford, 2015): 135. 
